\title{
Employability Skill Development: Faculty Members' Perspectives in Non-Professional Programs
}

\author{
Emily Gregory \& Heather Kanuka \\ University of Alberta
}

\begin{abstract}
The purpose of this study was to explore faculty perspectives about employability and employability skill development through curricular activities in non-professional programs. Using pre and post semi-structured interviews, this study embedded employability skills in three academic courses to gain insight into faculty members' perspectives on employability skill development. Results reveal that the faculty members involved in the study addressed employability to differing degrees in their courses, yet each recognized the importance for students. The outcomes of this study support the need for the development of employability initiatives in higher education and highlights that faculty members can benefit from support in identifying and assessing the employability skills practiced in academic courses.
\end{abstract}

Universities are increasingly being pressured to provide measures to support attributes such as graduate employment, and access to a well-paying job (Campbell, Cooper, Rueckert, \& Smith, 2019). Unfortunately, the ability for institutions of higher education to provide metrics is not entirely straightforward because dimensions of employability have differential foci, relevance and understandings within and between disciplines (Römgens, Scoupe, \& Beausaer, 2020). For example, in medicine there is a required residency that ensures their graduates are employment-ready upon graduation versus the humanities where the focus is on the inner world of self through philosophy, language and literature, focusing on the development of critical, creative and complex thinking skills; the construct of being 'employment-ready' typically falls outside the scope of their programs. The differential foci on employment-ready graduates has, in turn, led to the question of how (or whether) to provide metrics in the non-professional programs. As Faculty members are gatekeepers to the process of integrating employability into the curricula, understanding their perspectives on employability is needed in order to understand how to measure employability skills in the non-professional programs.

The aim of this study was to explore Faculty members' perspectives about employability and employability skill development in their non-professional undergraduate courses. An assumption underpinning this study is that it is possible to work with Faculty members in the non-professional faculties to integrate employability skill development into their courses. We begin with providing an overview of the literature, the research design, a discussion of the findings, conclusion and thoughts on further research in this area.

\section{Background to the Study and Overview of the Literature}

Institutions of higher education play an important role in the knowledge-based economy through the development of human capital; through their education students develop knowledge, skills, and attributes that they will apply when they enter the workforce (Molla \& Cuthbert, 2015; Knight \& Yorke, 2002; Yorke, 2004). This perspective presents higher education as an investment for both students and governments, one that will ideally benefit the whole of society through a strong economy. In simpler terms, a university education is expected to lead to positive employment outcomes for students (Yorke, 2006), and is one of many intended and unintended outcomes of a higher education. As Gedye and Beaumont (2015) explain, "massification [of higher education] has led to increased competition for graduate employment and a reduction in the currency of a degree" ( $p$. 406). Securing paid employment post-graduation is dependent on a variety of factors including the labour market, economy, and one's 
employability (Gbadamosi, Evans, Richardson, \& Ridolfo, 2015). As one might expect, many governments have also questioned the relevancy and quality of publicly funded higher education programs, especially as these programs are funded in part by the public (Molla \& Cuthbert, 2015).

\section{Employability Versus \\ Employment: It's More Than Just 'Getting a Job'}

Employability is an individual's ability to obtain and maintain employment, and is achieved through employability skill development. It is influenced by a variety of factors, such as interests, preferences, abilities, level of education, and socio-economic variables (Molla \& Cuthbert, 2015; Pegg, Waldock, Hendy-Isaac, \& Lawton, 2012; Yorke, 2006). Differing perspectives on employability and employability skill development can also incorporate aspects of identity, such as being satisfied and successful, or contributing to the community and economy. This leads to understanding the construct of employability as more than simply getting a job; nor should it be conflated with employment (Artess, Hooley, \& Mellors-Bourne, 2017; Yorke, 2006). Hence, graduates' employment rates are not an indicator of their employability; rather they are an indicator of the economic climate and socioeconomic factors influencing these graduates. Employability can also be understood as an individual attribute, which may vary between individuals and is dependent on multiple factors (Molla \& Cuthbert, 2015; Pegg, et al., 2012; Yorke, 2006). In this study, employability is the construct/phenomenon under investigation; employability skills are the concepts that explain employability. Hence the acquisition of employability skills determines one's employability.

\section{Employability Within the Context of Higher Education}

Although it is debated as to whether or not the employability agenda is welcome in higher education, governments, employers, and students expect that higher education institutions will be involved in preparing graduates for future work (Brown, 2015; Molla \& Cuthbert, 2015; Star \& Hammer, 2008; Tymon, 2013). Governments who fund higher education expect accountability and a return on investment (where a return on investment results in employed graduates who contribute to the economy) (Molla \& Cuthbert, 2015; Tymon, 2013). For example, in Ontario there are currently 10 new measurement metrics for publicly funded universities, seven of which are employment and/or career related (see: https://www.ontario.ca/page/all-college-and-university-strategic-mandate-agreements).

Employers manage their workforce with support from higher education through work experience programs and the recruitment of graduates. Additionally, there appears to be growing rhetoric from employers that many graduates do not possess the appropriate skills required for the workforce (Jackson, 2012; Molla \& Cuthbert, 2015; Moore \& Morton, 2017; Tymon, 2013). This skill mismatch, whether it is accurate or simply a perception, pushes higher education institutions to address employability. There are many reasons why students continue their education past secondary studies, yet in Canada the primary motivations are career related (Canadian University Survey Consortium, 2016). Data from the Canadian University Survey Consortium also reveals that students expect a university education will help them obtain a rewarding career. Future employment is a crucial priority for many university students, though they also recognize a degree may not guarantee an entry-level job (Tymon, 2013). Tymon suggests that graduates are aware they need to develop additional skills, beyond technical skills and academic knowledge, for career success. This situation is likely to be exasperated by the pandemic - as is illustrated by a report by Statistics Canada (October, 2020; see: https://www150.statcan.gc.ca/n1/daily-quotidien/200508/ dq200508a-eng.htm). This report illustrates the devastating effect of the Covid 19 pandemic, with unemployment reaching staggering numbers; though it needs to be noted that the impact varies by sector.

Co-curricular and extracurricular activities are proposed as a key method to increase students' employability, most notably through work experience programs (Artess, Holley, Mel- 
lors-Bourne, 2017; Mason, Williams \& Cranmer, 2009; Pegg, et al., 2012). Work experience programs provide students with opportunities to enhance their skills in a real-world setting, learn about work settings, and network with potential employers (Mason, et al., 2009; Pedagogy for Employability, 2006). However, not all academic programs offer work experience opportunities to their students and/ or some work experience opportunities are of such poor quality the benefits and opportunities are not realized for participating students. Additionally, if programs exist students may not be able to access them for a variety of socioeconomic factors. The prominence of unpaid internships also raises questions about the exploitation of students (Osborne \& Grant-Smith, 2017). The problem with pushing employability outside of the classroom is that it assumes all students will have equal access and opportunity to participate. Consequently, the integration of employability initiatives has also been proposed in higher education curricula.

There are ways to embed employability in curricula that will not undermine subject learning (Brown, 2015; Pedagogy for Employability, 2006; Yorke, 2004). Knight and Yorke (2002), for example, argue that employability can be integrated into any academic subjects without compromising academic content or freedom. Employability and subject learning do not need to be oppositional (Pedagogy for Employability, 2006). Embedding employability into the curricula can be as simple as helping students recognize what skills they are learning and how these skills are important outside of academia (Brown, 2015; Pegg, et al., 2012; Knight \& Yorke, 2002). Students are likely already developing many skills in their academic courses that will help them in future employment. Skills, such as communication, problem solving and working with others are enhanced through in-class presentations, discussions, assignments, and lab work. Rather than adjusting curricula, faculty members can help students to recognize the skills they are developing and help increase their self-efficacy regarding these skills (Artess, Hooley, \& Mellors-Bourne, 2017; Brown, 2015). Although there is a significant amount of research about embedding employability in course curricula, as well as resources to support faculty, there is a gap in how willing and able faculty members are to take this on, in addition to a lack of support services to assist in integrating employability into their curriculum. Top-down approaches also risk ignoring diversity between disciplines and subverting faculty members' academic autonomy (Knight \& Yorke, 2002). These issues raise concerns about how to engage faculty members in incorporating employability into their courses.

This study aimed to address this gap in the literature by gaining a better understanding of how to engage faculty members in incorporating employability into their courses. The overarching research question guiding this study was: What are faculty members' perspectives on employability skill development within their non-professional undergraduate courses? The outcomes of this study can be used by academic communities and institutional career services about how to work with faculty to design and implement programs targeted at developing employability skills in non-professional undergraduate programs.

\section{Research Design}

The design of this study was based on the Career Integrated Learning project at Memorial University. This project's researchers, Rob Shea and Rhonda Joy, worked with faculty members at Memorial University to identify competencies practiced in courses (informal communication). With some modifications, the Career Integrated Learning project served as a conceptual framework for this study, focusing on employability skills. It was paramount that faculty members had the autonomy to determine what employability skills were relevant to their course and that they did not have to make changes to their course curricula.

As the purpose of our study was to explore the perceptions of Faculty members in non-professional programs, the data collection was designed to elicit in-depth responses from participants on their views of employability and employability skill development in their courses through semi-structured interviews. While unstructured interviews also elicit in-depth re- 
sponses, we chose semi-structure interviews to ensure the interviews were guided by the literature, and as such, ensuring we are collecting data that builds on what is already known. The semi-structured questions were conducted using generic qualitative research as described by Merriam (1998): Generic qualitative research is used to "discover and understand a phenomenon, a process, or the perspectives and worldviews of the people involved" (p. 11). Caelli, Ray and Mill (2003) described generic qualitative studies as

... those that exhibit some or all of the characteristics of qualitative endeavor but rather than focusing the study through the lens of a known methodology they seek to do one of two things: either they combine several methodologies or approaches, or claim no particular methodological viewpoint at all. (p. 2)

The interview questions were designed to draw on the literature with respect to the complexities on employability metrics in the non-professional faculties, faculty resistance to the integration of employability into their courses and in what ways (if at all) are faculty addressing employability skill development in their courses.

\section{Participants}

Faculty members were selected as participants for this study because, in many ways, they are the gatekeepers to students. If they are indifferent about employability and/or are unaware of employability development through classes, they may be unlikely to discuss this with students. As such, faculty members' perspectives were considered essential to gaining further insights on how to gain a better understanding on employability skill development within non-professional undergraduate courses.

Purposive sampling was used to select faculty members from three different faculties at the research site. Faculty members were recruited based on two key criteria: must teach a 200 - or 300-level undergraduate course ( $3^{\text {rd }}$ or $4^{\text {th }}$ year course) and must teach in a non-professional faculty. Twenty faculty members were initially contacted and invited to participate in the study, which resulted in the recruitment of two faculty members, both in the natural sciences. To ensure maximal variation sampling a final participant was recruited from the social sciences.

\section{Data collection}

Non-professional faculties at the university, where the academic program does not lead to a professional accreditation, were selected as the specific research sites. Semi-structured interview data were collected through two interview sets with faculty members (one at the onset of their courses and one at the end of their courses). The research site was at a large, research-intensive university in Western Canada. To commence data collection, course syllabi were obtained from each of the participating faculty members. Using the Conference Board of Canada's (n.d.) inventory of employability skills, an analysis of each syllabus was undertaken to identify the employability skills that could be addressed in the course. This inventory includes 56 skills organized into three categories: fundamental skills, personal management skills, and teamwork skills. A unique inventory for each course was created.

Next, the faculty members participated in the semi-structured interviews. The interviews asked faculty members: (1) their perspectives on employability skill development in higher education, (2) if employability matters in higher education, (3) the extent to which students develop employability skills through their academic course work, and (4) in what ways they currently address employability in their coursework. The interviews were conducted in person. The project was reviewed and approved by the human research ethics board at the research site.

The faculty members also provided feedback on the employability skills inventory for their course. Faculty members made the final decisions as to which skills were included in their inventory. At the end 
CANADIAN

JOURNAL OF

CAREER

DEVELOPMENT
REVUE

CANADIENNE DE DÉVELOPPEMENT

DE CARRIĖRE of the term, the post interview was conducted with each of the participating faculty members. The post interviews were also semi-structured and similar questions were asked as in the first interview, but included three additional questions based on the analysis of each faculty member's syllabus, which identified the employability skills that could be addressed in their course. The additional questions asked: (1) what did you do to help students recognize their employability skill development, (2) to describe where they think the balance is between what they do for employability and (3) what students need to do, and how they will continue to address employability in their courses. All interviews were audio recorded and transcribed.

\section{Results}

Data analysis began with an initial thematic overview of each participant's interviews, followed by a member check. Analysis of interviews used a general qualitative approach (Merriam \& Tisdell, 2016). Quirkos ${ }^{\mathrm{TM}}$, a qualitative data analysis software, was used to organize the data in categories and subcategories. Following are participant details and thematic categories with examples from the participants' interview transcripts.

\section{Participant Details}

Codes were assigned to each of the faculty members. Faculty members $\mathrm{A}$ and $\mathrm{C}$ teach in the natural sciences; both are full professors and have previously also held senior administrative roles at the institution. Faculty member A teaches in a field that has industry connections and students can attain employment in this industry at the bachelor's level. Faculty C teaches in an applied field and also has connections to industry. Both $\mathrm{A}$ and $\mathrm{C}$ have had long teaching careers. Faculty member B teaches in the social sciences and is an Associate Professor. This participant also served as an Associate Undergraduate Chair at the time of data collection.

\section{Employability Perspectives at the Beginning of the Course}

In the first interview, five thematic categories emerged: definitions of employability, importance of employability, skills awareness, curriculum and teaching, and career exploration for students. Following is a description of each.

\section{Definitions of Employability}

This project asked the participating faculty members to consider a concept that is not often at the forefront of their work: employability. As employability is not the focus of their work, participants were asked to describe their understanding of employability and employability skills. Each of the participants touched on how employability is about getting a job and gaining skills that will help in this pursuit.
Participant B responded:

If I'm forced to, if I'm compelled to, I would think of employability as the capacity to bring skills to a particular job, but I guess that's what employability is. Having a list of skills that you use to convince an employer to take you on.

This participant also described employability as a "catchphrase" focusing on skills that are valuable in work, but also emphasized that these skills are "not the whole point of work" (Participant B).

Participant $\mathrm{C}$ expanded on employability to include not only the students' skills, but also their interests: "employability is the ability for a student to be employed in their number one job area ... that's different than getting a job at McDonalds. It's getting a job that uses their skill set and captures their interests." These definitions of employability focus on securing work, on becoming employed following graduation. Employability skills, therefore, were perceived by participants $\mathrm{A}$ and $\mathrm{B}$ as securing work. Participant C's perspective revolved around the notion that students are looking for work in their areas of interest, and that this work will ideally be commensurate with their level of education.

\section{Importance of Employability}

All participants addressed the degree to which employability is important to them, and to 
students. For participant A, the extent to which employability matters "depends on the program that you're teaching in." Though it was also acknowledged that by participant A that: "From [the students'] perspective it's much more important that they develop these skills to be employable. Particularly given the job market right now, at least at the bachelors level." The importance of employability may vary between academic disciplines and there may be a greater focus on it in more applied areas, as participant $\mathrm{C}$ notes: "Most students come into [our faculty] with the expectations of getting an education to work and to be employed in the area of agriculture." Participant B teaches in the social sciences, a less applied field. This participant recognizes that employability is not "part of what we do in the classroom." However, Participant B also recognizes the importance of employability: "I think it matters to entering students, I think it matters to their parents. I think it matters to students in their last term." Participant B also stated that employability is "part of the sales pitch" of higher education.

The value of employability, therefore, varies and we cannot assume all faculty members will recognize, care, or even view employability as their responsibility - though the participants' in this study indicated that they know employability is important for their students. Acknowledging that the sample is small, the data also indicate the possibility of uneven importance between disciplines.

\section{Skills Awareness}

During the first interview, the skills inventory was reviewed with the faculty members to adjust and gain further clarity about their courses. Consequently, considerable time was given to discussing skills and the ways in which their students develop, or do not develop, skills in their courses. For participant B: "I think actually the most important skills that they gain from university are probably creativity, hard work, work ethics, and a capacity to roll with the punches of work in the work world." For this participant, recognizing that students develop marketable skills but expressed concern that they are not aware of their skill development. "I don't think they are often aware of the skills that they've learned. Part of this is sort of denigration of the arts and humanities - they sort of capitulate to that idea that it's not skill building." However, participant A, who teaches in the natural sciences, reinforces that his own awareness of students' skill development was minimal: "Given my reaction to your document, it's pretty clear that my awareness was pretty low. Projecting I would like to think they were at least as naive as I am, or they might be more conscious of it." Participant C suggested that skill awareness may also change depending on where students are at in their degree: "Some of these kids in first year aren't even thinking about employability yet ... But some of the senior students are actually applying for jobs now, and once that happens, they're totally engaged.' Similarly, Participant B acknowledged: "students often don't, until the very end, think carefully about what they're doing. I think they chug through the classes - what class do I need to take next - and they go from class to class".

The skills students are learning in higher education may seem intangible or non-transferable to other contexts, such as work. Participant B explains: "I think that they sometimes throw their hands up in the air and say 'well I learned to read Chaucer but nothing else.' But learning to read Chaucer is a big deal." Participant B described skill translation as meaning understanding what skills are learned when reading Chaucer - as the issue for many students: "I would say that they're probably developing skills that they don't know - there's a problem with translation, how to describe these skills that they've developed in school in a way that makes sense to an employment situation."

Assisting students with skill translation may help to increase their awareness. Participant B explained that "they [students] often do not have the language for it" and could help them with this translation. This participant reflected that "if it's a matter of spending 20 minutes every two weeks on translation" this would be valuable to students and feasible. Participant B feels that students do not recognize that the skills they are learning can be important for future work, such as communication or "taking large bundles of information and turn- 
CANADIAN

JOURNAL OF

CAREER

DEVELOPMENT
REVUE

CANADIENNE DE DÉVELOPPEMENT

DE CARRIĖRE ing them into something useable." The issue, according to participant $\mathrm{B}$, stems from translation; the students do not know how their academic skills transfer to other contexts, such as work.

Participant C tied students' awareness of employability skills to their engagement in his course: "Some students will be quite content with just getting enough to get by, which those ones likely won't gain much employability skills." For participant C: "If you have somebody who just comes to class, just does the exam and the project material, they wouldn't get as much out of it for employability, because they wouldn't have gotten their hands as dirty as the students doing the extra work."

For the faculty who participated in this study, awareness of employability skills was an issue. They noted that in the earlier years of their degrees, students may not yet consider employability and where they want to go next. Or students, and faculty, may lack the language and tools to identify and translate skills to non-academic contexts. Or skill awareness may be connected to students' engagement in their courses. Faculty appear to be aware that increasing their awareness of employability skills, may also help students become more aware of these skills. Specifically, when faculty members are provided with support on how to identify possible employability skills in their courses (e.g., read Chaucer, or complete a lab assignment) they can, in turn, assist their students in translating these skills to non-academic situa- tions, such as employment settings.

\section{Curriculum and Teaching}

When asked if and how employability is addressed in their courses, the faculty members answered candidly: "The honest answer to that would be I don't" (participant A). To participant B, employability is not a focus of teaching, but recognizing the role it will play in students' lives:

I teach in the humanities, and my background is in the humanities, I'm not thinking about jobs. I'm thinking about people, whole people. Who are also workers, right? I don't avoid the fact that students are going to be workers one day. But I'm not in the classroom saying you'll need this so that you can be a good social worker, or a good receptionist.

Conversely, participant $\mathrm{C}$ addresses employability throughout his teaching: "Well I talk to them a lot about it ... about taking advantage of opportunities." Consequently, employability plays a diverse role in faculty members' teaching: from unintentional to explicit.

For the participants in this study, academic content is king, leaving employability on the sidelines. Participant A explained: "... in the courses we focus exclusively on the academic content." Academic content aims to help broaden students' perspectives and develop a foundation they will need in higher level courses. "We teach students how to pay attention to the world around them, and interpret it, and figure out how to maneuver through it (Participant B)." However, Participant B adds "I don't talk about what we do in the classroom through the lens of employability."

The faculty members considered ways they address employability in their classes, even if this is unintentional. Participant B discussed department pressure to address skill development:

The chair has asked that, in an ongoing way, we make general references to the skills they're building. So once in a while we'll read a really hard text and I'll say, 'do you see what you did there? And you could do this, you could use this skill of reading Simone De Beauvoir to read a government document. This can be just as obscure and difficult. So, I do that from time to time.

In addition to content being king, there are multiple reasons for not addressing employability in the participants' teaching. Participant A suggested limited time for faculty members. "Where I think we're failing them, and maybe that's too strong of a word, is giving them more opportunities to do the sort of writing they might do once they get out. And that's a logistical issue." This participant suggested providing students with writing assignments they would build on over the semester while receiving ongoing feedback. How- 
ever limited time seems to prevent doing this type of assignment. Devoting time to employability would also take away from students' academic work. Participant B explained: "One of the arguments would be that if we devote half of a class to career skills and CV building, students have lost half a class to do something that they'll never do otherwise, which is scholarly work."

In addition to limited time, faculty members also have limited experience in teaching about employability, as participant B explains: "Most of us have had a few crap jobs when we were students and then moved into this environment, which is very specific and it's not like other jobs." Students have a great deal of contact with faculty members, but we cannot assume all faculty are able or willing to teach about employability. Participant B recognized there is value in having faculty do this, but questioned if faculty are well suited to address these areas. "I suspect it would probably work better if faculty were somehow involved, but we're not career counsellors and we do not know much about the world of work."

\section{Career Exploration for Students}

Although the participants addressed employability to varying degrees, they all recognized the value in helping students learn about potential career options and in incorporating these options into their teaching. Participant A mused: "to some extent, we need to be cognizant of what our stu- dents are doing after they get out." Alternatively, participant B connects current students with alumni from the program: "I'm putting our undergraduates, mostly senior undergraduates [with alumni]... So they're talking to one another and learning about the world of work." These opportunities help students learn about what careers they can pursue post-graduation and how they can apply what they have learned through their degree to the world of work.

\section{Employability Perspectives at the End of the Course}

The faculty members each participated in a second interview at the end of the term. The purpose of the post interview was to ask the participant if, and how, their perspectives on employability changed based on the employability skills information and identification provided at the onset of their course.

\section{Definitions of Employability}

The faculty members' definitions about employability skills remained consistent between the interviews. However, their perspectives in the second interview expanded to capture experience and technical skills. Whereas their initial definitions focused on demonstrating a specific skill set to secure employment, the definitions at the end of the term expanded on what this skill set needs to include. Participant A explains: "We're looking at things like communication, basic numeracy and literacy sorts of skills, ability to frame problems, a bunch that they label as personal management skills. Looking over those you could actually say that you could group those together as being a responsible adult or sentient being." This expanded definition is possibly the result of a new vocabulary. Specifically, the employability skills inventory prompted the faculty members to reframe their teaching materials to consider students' skill development.

In the post interview, the participants' perspectives on employability also expanded to consider students' futures beyond just getting a job. Participant A touched on the "ability to function competently in a workplace". This expanded the definition from 'getting a job', to also maintaining and succeeding in a job. For participant $\mathrm{C}$, employability moved to involving a "career type position", where students want to be in the long-term. In this sense, employability involves not only securing work, but flourishing in this work.

\section{Career Exploration}

Faculty members in the post interview also commented on how they can help students learn about their career options or gain hands-on experience in their field. Participant $\mathrm{C}$ described how his course, and notably the experiential learning opportunities (labs, farm visits), helped students learn more about their career interests:

Other students, their vision is to get to vet school and that 


\section{Employability Skill Development}

14

takes a bit longer. And we have some students who the lights got turned on in this class. There are three or four of them who said 'I thought I wanted to be a vet, and now I want to work in agriculture'.

Through this course, students were exposed to career options outside what they were previously considering. These students could begin to learn about what work would be like in a different area of this industry and what skills they would need to work in this area. Participant A suggested internships as a way to support students and a "good way to improve their employability".

Students in participant B's discipline have a wide variety of career options; their degree does not point to a specific career or lead down a linear career path. For these students, they must consider a variety of options. Often, they seek out support for exploring their options from their faculty members, such as participant B: "I am faced with helping students think about their future as workers and they sit in this office and I need to have the skills to talk to them about the skills they have that can get them employment."

\section{Changes}

The project did not prompt significant changes for the faculty members perspectives about employability, or their teaching, rather it nudged them towards considering the non-technical skills students develop in their courses.
When asked how his perspective on employability changed over the term, participant A explained:

It has a little bit, and I think it's mostly because of talking with you and also looking over the handout that you had given the class. It kind of fleshed out more what I had been putting in the soft skills bucket. It made it a little more specific and a little more, a few more dimensions than I had really been thinking about.

For participant $\mathrm{C}$, the project demonstrated the value of developing non-technical skills, in particular, common sense and communications. The project also encouraged these faculty members to be more explicit with their students about what they are learning and practicing in their courses. Participant A suggested adding "maybe another bullet point in the intended outcomes of a lab."

Participant B felt that employability did not change over the semester. This participant had anticipated that the skills inventory would encourage considering, even in minimal ways. Though this participant recognized an increased awareness of employability:

I think that as a result of you talking to me a couple of times, coming to class, giving me something to put up on [Moodle] about your project, I've begun to think a little more about employability. But just in loose ways.
Despite initial interests, Participant B was unable to devote much thought to employability over the course of the term. As discussed in the first interviews, the faculty felt they had limited time to address all the necessary academic content in their courses. Consequently, discussions about employability, as participant B mused, became "one of the things that fell off the table". It is important to note that the faculty members were not expected to discuss, or even refer to, the skills inventory with their students. Participant B suggested it would be ideal to spend a brief amount of time discussing skill awareness and translation with students:

In a perfect world, I think that I would spend a bit of time at the end of each class, like in May or December, to talk a little bit about how what we've done in the classroom could translate into something we might call employability. I would like to do that, but I mean maybe what I do is find somebody, like yourself, to come and give a 15-minute thing at the end of every fourth-year class. Just to give students skills, or give them the translation capacity.

Addressing employability does not require significant changes to curriculum or teaching practices. As the participants in this study described, it can include adding skills or intended outcomes to assignments or labs or discussing with students how a skill might help them in future work. 
Participant B anticipated more faculty members would be interested in employability, particularly if it does not require them to change their teaching by much.

I think also probably a lot of faculty would be interested in thinking about employability, just broadly, and the chart that you gave me at the beginning of the semester I had never seen anything like that. It was really, really helpful.

\section{Skill Awareness}

The participants agreed that students do develop employability skills in their courses. However, they also agreed that students' awareness of this development is limited, as participant B notes: "I think that they've been told all along that they need to go to university so that they can get skills, or that they can be in a position to be employed. But I think you're right, I don't think they know. I don't tell them". Students' limited awareness may result from not thinking about what they're learning as skill development and not recognizing that their academic work may have value to an employer. Participant A described students' misguided awareness as aspirational that they are getting more out of their studies than just academic knowledge:

They would like to think they are developing skills, that's why they're here and suffering through 4 years, or five years, or six years of this. They hope they'll get something out of it. That really speaks to why they can't identify the skills they're learning. Part of it is they're not thinking of the subject or the content material that they are learning, or that they're learning to do, as really part of that target skill set. And I don't think they are, again because we haven't really been framing things in that fashion.

Awareness may also result from taking the time to think about skill development, to reflect on what is going on, as participant C explains: "Sometimes I think students, if they are totally passive, they won't stop to think if they will use it, or not. They will just write it down, memorize it, and go through the assignments and exam. That's it." Participant B described the students who will be better off as the ones who "pay attention at a meta level to what's going on." If faculty members are more aware of employability skills, as participant A notes, they are better able to "remind students what they're getting out the course, besides the academic content". Participant A noted further: "We've never really thought about it being necessary to communicate that."

\section{Responsibility}

Faculty members, and by extension institutions of higher education, are responsible for the academic development of students. However, where the responsibility for employability development falls is less clear. On this front, participant A asserts: "I would like to think we could all agree that at the end of the day, the academic side of the employability question is our responsibility. Where people will diverge is to what extent our academic program will help students mature in terms of the other side, the soft skills side." The participants in this study expressed diverging opinions about this issue, possibly due to differences in their academic disciplines. Participant $\mathrm{A}$ and $\mathrm{B}$ both highlighted that students cannot, and should not, rely on them to develop their employability. Participant A literally chuckled:
Well I think the fact that they are telling you that their university isn't taking any, or much, responsibility is a very realistic perspective that they should have. They look at their professors and think, 'my god, if I have to depend on them to get a job, I'm hooped.'

For participant B, developing and enhancing students' employability simply falls outside of the scope of the role in higher education:

I don't think it's my responsibility. I think it would be a good thing for me to do to help them translate it. I'm here as an intellectual and an administrator of intellectual programs. I can't do that. Maybe if there are an extra three days a week. 
CANADIAN

JOURNAL OF

CAREER

DEVELOPMENT
REVUE

CANADIENNE DE DÉVELOPPEMENT

DE CARRIĖRE
From these perspectives, students need to own their responsibility and not expect their faculty members will enhance their employability. However, participant C's perspective differed, noted that "a bit more empathy for students being employed than do some other people." This participant equated this empathy with the applied nature of his academic studies and his current teaching. Participant C's discipline is targeted towards a very specific industry, and his course incorporates opportunities for the students to engage with this industry. The other courses did not involve industry engagement.

\section{Summary, Discussion and Conclusions}

This study aimed to explore faculty member perspectives about employability skill development in non-professional undergraduate programs. Employability is an individual's ability to obtain and maintain employment, and employability skills are the skills that enhance employability. Employability's role in higher education is contested, yet it is, nevertheless, expected that universities will help prepare students for future work (Brown, 2015; Molla \& Cuthbert, 2015; Star \& Hammer, 2008, Tymon, 2013).

To some degree there is an expectation that a university degree will least help students develop employability skills. Prior literature on this topic also reveals that "career development learning has a demonstrable positive impact on the graduate employability of higher education learners" ( $\mathrm{p}$. 56, Bridgstock, Grant-Imaru, \& McAlpine; 2019). However, the finding of this study reveals that the responsibility for employability skill development was not wholly considered to be the responsibility of faculty members. On this point, Pegg et al. (2012) argues that a uniform approach will not work as employability is too complex. Students, faculty members, career services, and employers must all be involved in employability development. The model for this project, which was based on Memorial University's Career Integrated Learning, is a valuable opportunity to support faculty members to address employability in their course work. By working with faculty members to identify the employability skills developed in their curriculum, support services (such as career facilities) can help them learn more about employability, and also help students enhance their awareness of their employability skills. Relatedly, prior research by Goodwin, Goh, Verkoeyen and Lithgow (2019; see also Monteiro, Ferreira, \& Almeida; 2020).) conclude that "universities should integrate institution-wide, course-level employability skills articulation assignments for students in all years of study and programs" (p. 445). Goodwin et al assert further that policy and funding should be provided to support students in recognizing and articulating their employability skills, in addition to support for Faculty members in the development efforts. For example, research by Leach (2015), showed a positive impact on students with respect to "their feelings of self-confidence, self-worth and enhanced ability to articulate their employment credentials with employers" (p. 53). These studies are in alignment with our findings, in that responsibility does not lie with one group, rather employability development must be a collaborative effort in higher education.

The outcomes of this study also show that a uniform approach will not address employability development for all students, which is consistent with prior research (e.g., Pegg, et al., 2012). Also consistent with prior research (e.g., Artess et al., 2017; Paek, Leong, Johnson, \& Carleton Moore, 2021), structural, program and curricular changes, along with extra-curricular opportunities, can help students develop their employability. The findings of this study reveal that it is also possible to encourage some Faculty to incorporate employability into their courses with adequate support. While institutional policy could mandate the integration of employability into the curriculum, it would likely be met with resistance alongside substantive support resources. Alternatively, initiatives to enhance employability in higher education could focus on the faculty members who are willing to discuss and consider ways to incorporate employability into their teaching. These faculty members must be provided with both information and support as they cannot be expected to know how their course work relates to employability. Institutional career 
services are likely best suited to provide this support.

\section{Limitations and Future Research}

This study had a number of limitations, leading to the need for further research. The most obvious limitation is that this project included only three faculty members who teach in non-professional faculties. Recruiting faculty members for this project was challenging given the contentious topic and time commitment required (pre and post interviews as well as the use of class time for a presentation and survey administered to the students). The low participation rate also suggests there could be little interest in involving employability into course work in the non-professional degrees. The first author of this study had a prior relationship with each of the faculty members who participated in the project, two through a professional role in career services, and the third through a previous academic project. The prior relationship most likely influenced the faculty members to participate in the project. Furthermore, they may have had a prior interest in supporting the career interests of their students. Their results, as such, may not be representative of faculty members in higher education.

In future research a large scale, pan Canadian, anonymous survey with open and closed questions might provide an opportunity for generalization across Canadian universities and/or institutions of higher education. Collecting this information is important given the strong opinions on employability in the non-professional faculties. Another area for future research might be to explore the resistance to integrating employability skill development in the non-professional faculties as well as perceptions on employment metrics.

\section{References}

Artess, J., Hooley, T., Mellors-Bourne, R. (2017). Employability: A review of the literature 2012 to 2016. Higher Education Academy Report. [Online]. Available: https:// s3.eu-west-2.amazonaws.com/ assets.creode.advancehe-document-manager/documents/hea/ private/resources/employability a review of the literature 1568037358.pdf

Bridgstock, R., Grant-Imaru, M., \& McAlpine, A. (2019). Integrating career development learning into the curriculum: Collaboration with the careers service for employability. Journal of Teaching and Learning for Graduate Employability, 10(1), 56-72.

Brown. K.E. (2015). Employability and the liberal arts: A career readiness initiative. Thought \& Action: The NEA Higher Education Journal, 1(2), 49-56. [Online]. Available: https:// www.naca.org/JCAPS/Documents/Developing_Employability Skills.pdf

Caelli, K., Ray, L., \& Mill, J. (2003). "Clear as mud": Toward greater clarity in generic qualitative research. Inter- national Journal of Qualitative Methods, 2(2), 1-24. https://doi.org/10.1177\% 2F160940690300200201 Campbell, M., Cooper, B., Rueckert, C., \& Smith, J. (2019). Reimagining student employability: a case study of policy and practice transformation. Journal of Higher Education Policy and Management, 41(5), 500-517. https://doi.org/10.108 0/1360080X.2019.1646379 Canadian University Survey Consortium (2015). 2015 Graduating university student survey. [Online]. https://www.cuscccreu.ca/CUSC 2015 Graduating_Master\%20Report_English.pdf

Canadian University Survey Consortium (2016). 2016 Firstyear university student survey. [Online]. Available: https:// www.cusc-ccreu.ca/publications/CUSC 2016-First-YearReport-EN.pdf

Conference Board of Canada (n.d.). Employability Skills. [Online]. Available: https:// www.conferenceboard.ca/edu/ employability-skills.aspx Gbadamosi, G., Evans, C., Richardson, M., \& Ridolfo, M. (2015). Employability and students' part-time work in the UK: Does self-efficacy and career aspiration matter? British Educational Research Journal, 41(6), 1086-1107. https://doi. org/10.1002/berj. 3174

Gedye, S., \& Beaumont, E. (2018). "The ability to get a job": Student understandings and definitions of employability. Education + Train- 
CANADIAN JOURNAL OF CAREER DEVELOPMENT
REVUE CANADIENNE DE DÉVELOPPEMENT DE CARRIĖRE ing, 60(5), 406-410. https:// doi:org/10.1108/ET-10-2017$\underline{0159}$

Goodwin, J. T., Goh, J., Verkoeyen, S., \& Lithgow, K. (2019). Can students be taught to articulate employability skills? Education \& Training, 61(4), 445-460. https://doi. org/10.1108/ET-08-2018-0186

Jackson, D. (2012). Business undergraduates' perceptions of their capabilities in employability skills: Implications for industry and higher education. Industry and Higher Education, 26(5), 345-356. https://dx.doi.org/10.5367/ihe.2012.0117

Knight, P T., \& Yorke, M. (2002).

Employability through the curriculum. Tertiary Education and Management, 8, 261-276.

Leach, T. (2015). Graduates' experiences and perceptions of career enactment: identity, transitions, personal agency and emergent career direction. Research in PostCompulsory Education, 20(1), 50-63, https://doi.org/10.1080/135967 48.2015.993872

Mason, G., Williams, G., \& Cranmer, S. (2009). Employability skills initiatives in higher education: What effects do they have on graduate labour market outcomes? Education Economics, 17(1), 1-30. https: //doi.org/10.1080/0964529080 2028315

Merriam, S. B. (1998). Qualitative research and case study applications in education. San Francisco: Jossey-Bass.

Merriam, T. B., \& Tisdall, E. J. (2016). Qualitative Research:
A Guide to Design and Implementation (4th ed.). San Francisco, CA: Jossey-Bass Higher and Adult Education Series Molla, T., \& Cuthbert, D. (2015). The issue of research graduate employability in Australia: An analysis of the policy framing (1999-2013) The Australian Association for Research in Education, 42, 237-256. https://doi.org/10.1007/ s13384-015-0171-6

Monteiro, S., Ferreira, J. A., \& Almeida, L. S. (2020). Self-perceived competency and self-perceived employability in higher education: the mediating role of career adaptability. Journal of Further and Higher Education, 44(3), 408422. 2 https://doi.org/10.1080/ 0309877X.2018.1542669

Moore, T., \& Morton, J. (2017). The myth of job readiness? Written communication, employability, and the 'skills gaps' in higher education. Studies in Higher Education, 42(3), 591609. https://doi.org/10.1080/03 075079.2015.1067602

Osborne, N., \& Grant-Smith, D. (2017). Resisting the 'employability' doctrine through anarchist pedagogies \& prefiguration. Australian Universities' Review, 59(2), 59-69. [Online]. Available: https://files.eric. ed.gov/fulltext/EJ1157049.pdf Paek, S., Leong, P., Johnson, P., \& Moore, C. (2021). Is GPA Enough? A Platform for Promoting Computer Science Undergraduates' Pursuit of Career Related Extracurricular Activities. International Jour- nal of Technology in Education and Science, 5(1), 1-6. https:// doi.org/10.46328/ijtes.146

Pedagogy for Employability Group (2006). Pedagogy for employability. Learning and Employability Series One. York: ESECT and HEA. https://www.advance-he.ac.uk/ knowledge-hub/pedagogy-employability-2012

Pegg, A., Waldock, J., Hendy-Isaac, S., \& Lawton, R. (2012). Pedagogy for employability. York: ESECT and HEA. https://s3.eu-west-2. amazonaws.com/assets.creode. advancehe-document-manager/ documents/hea/private/pedagogy for employability update 2012 1568036839.pdf

Römgens, I., Scoupe, R., \& Beausaer thttps, S. (2020). Unraveling the concept of employability, bringing together research on employability in higher education and the workplace. Studies in Higher Education, 45(12), 2588-2603. https://doi. org/10.1080/03075079.2019.1 $\underline{623770}$

Star, C., \& Hammer, S. (2008).

Teaching generic skills: Eroding the higher purpose of universities, or an opportunity for renewal? Oxford Review of Education, 34(2), 237-251. https://www.researchgate.net/ publication/44839274 Teaching_generic skills_Eroding the higher purpose of universities or an opportunity for renewal

Tymon, A. (2013). The student perspective on employability. Studies in Higher Education, 
38(6), 841-856. https://www. researchgate.net/publication/322663153 Employability_Skill traits Management Quotient ESMQ - A Conceptual_Model_Proposal

Yorke, M. (2004). Employability in the undergraduate curriculum: Some student perspectives. European Journal of Education, 39(4), 409-427. https://doi.org/10.1111/j.14653435.2004.00194.x

Yorke, M. (2006). Employability in higher education: What it is - what it is not. Learning and Employability Series One. York: ESECT and HEA. https://www.advance-he. ac.uk/knowledge-hub/employability-higher-education-what-it-what-it-not

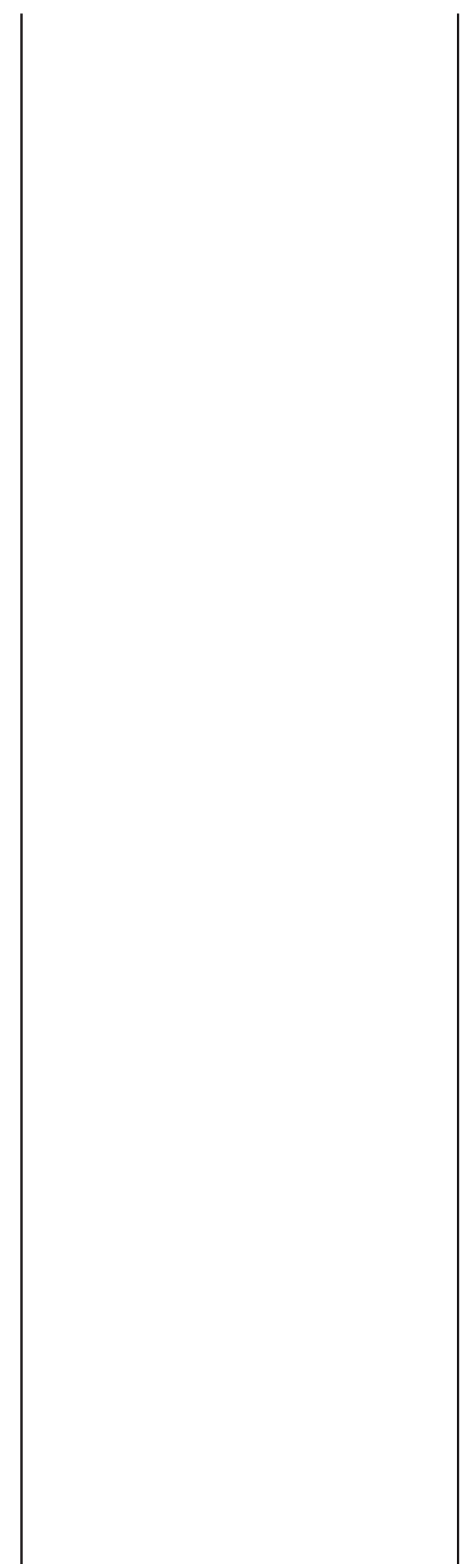

